\title{
Valorization of sunflower meal through the production of ethanol from the hemicellulosic fraction
}

\author{
Bruna Tavares ${ }^{1}$, Luciane Sene ${ }^{1} \&$ Divair Christ ${ }^{1}$ \\ ${ }^{1}$ Universidade Estadual do Oeste do Paraná/Centro de Ciências Exatas e Tecnológicas/Programa de Pós-Graduação Stricto Sensu em Engenharia Agrícola. \\ Cascavel, PR. E-mail: brutavares1986@hotmail.com (Corresponding author); luciane.sene@unioeste.br; divair.christ@unioeste.br
}

\section{Key words: \\ by-product \\ biomass \\ xylose \\ biofuel \\ optimization}

\begin{abstract}
A B S T R A C T
Sunflower is among the major oil seeds crop grown in the world and the by-products generated during the seeds processing represent an attractive source of lignocellulosic biomass for bioprocesses. The conversion of lignocellulosic fibers into fermentable sugars has been considered as a promising alternative to increase the demand for ethanol. The present study aimed to establish the fermentation conditions for ethanol production by Scheffersomyces stipitis ATCC 58376 in sunflower meal hemicellulosic hydrolysate, through a $2^{3}$ CCRD (Central Composite Rotational Design) factorial design. Under the selected

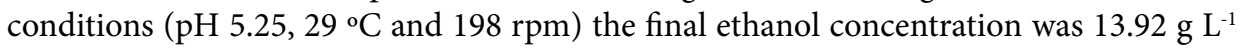
and the ethanol yield was $0.49 \mathrm{~g} \mathrm{~g}^{-1}$.
\end{abstract}

Palavras-chave:

subproduto

biomassa

xilose

biocombustível

otimização

\section{Valorização do farelo de girassol através da produção de etanol a partir da fração hemicelulósica}

\section{R E S U M O}

O girassol está entre as principais oleaginosas cultivadas no mundo e os subprodutos gerados durante o processamento das sementes representam uma fonte atraente de biomassa lignocelulósica para bioprocessos. A conversão de fibras lignocelulósicas em açúcares fermentáveis tem sido considerada uma alternativa promissora para aumentar a demanda de etanol. O presente estudo teve, como objetivo, estabelecer as condições de fermentação para a produção de etanol por Scheffersomyces stipitis ATCC 58376 em hidrolisado hemicelulósico de farelo de girassol através de um planejamento fatorial DCCR $2^{3}$. Sob as condições selecionadas ( $\mathrm{pH} 5,25,29^{\circ} \mathrm{C}$ e $198 \mathrm{rpm}$ ) a concentração final de etanol foi $13,92 \mathrm{~g} \mathrm{~L}^{-1}$ e o rendimento $0,49 \mathrm{~g} \mathrm{~g}^{-1}$. 


\section{INTRODUCTION}

Among the oil crops, sunflower (Helianthus annuus) is the one that presents the highest expansion rate in the world. According to the United States Department of Agriculture (USDA, 2015), the world production of sunflower seeds reached 35.8 million MT (metric tons) in the 2012/13 marketing year and 42.7 million MT in 2013/14, representing an increase of $19 \%$. For $2014 / 15$, the global production is expected to be 39.8 MT. Sunflower meal, the by-product of the oil extraction process, has been generally used as food supplement for non-ruminants (Hernández et al., 2011) and as biomass for power generation (Raclavska et al., 2011).

Lignocellulosic biomass is typically nonedible plant material composed primarily of the polysaccharides cellulose and hemicellulose. Lignin, a phenolic polymer that provides structural strength to the plant, is the third major component (Sluiter et al., 2010).

The economic feasibility of ethanol production from lignocellulosic materials lies on the efficient use of their sugar content. This implies not only the glucose obtained from the cellulose, but also the sugars released from the hemicellulose (Díaz et al., 2009). The dilute-acid hydrolysis pre-treatment is commonly used to separate hemicellulose and the resulting hemicellulosic hydrolysate can also be fermented to produce ethanol (Canilha et al., 2012).

The yeast Scheffersomyces stipitis, formerly known as Pichia stipitis, has a natural ability to convert hemicellulose-derived sugars into ethanol (Krahulec et al., 2012, Scordia et al., 2012). However, its fermentation efficiency is related to nutritional factors such as temperature, $\mathrm{pH}$ and oxygen supply, and toxic factors present in the hemicellulose hydrolysate (Du Preez et al., 1986; Prior et al., 1989), as well as the tolerance to ethanol and lignocellulose-derived inhibitors (Bellido et al., 2011).

Recent studies have presented sunflower biomass as a novel source of sugars from cellulose and hemicellulose (Camargo et al., 2014a) and for ethanol production by simultaneous saccharification and fermentation (SSF) (Camargo et al., 2014b). Although there are many studies in the literature on the physiology of $S$. stipitis and its potential to produce ethanol from xylose, reports on its performance in hemicellulosic hydrolysates derived sunflower by-products are still limited. Thus, the present study aimed at exploring the biotechnological potential of sunflower meal for ethanol production by S. stipitis from the hemicellulosic hydrolysate.

\section{Material ANd Methods}

Characterization of sunflower meal (Caramuru Alimentos, Itumbiara-GO, Brazil), dilute acid hydrolysis of the hemicellulosic fraction $\left(6 \% \mathrm{w} \mathrm{v}^{-1} \mathrm{H}_{2} \mathrm{SO}_{4}, 121^{\circ} \mathrm{C}, 20 \mathrm{~min}\right)$ and hydrolysate detoxification ( $\mathrm{pH}$ adjustment followed by adsorption with activated charcoal) were performed according to Camargo \& Sene (2014).

Scheffersomyces (Pichia) stipitis ATCC 58376 was maintained in YMA agar slants $\left(3 \mathrm{~g} \mathrm{~L}^{-1}\right.$ malt extract, $3 \mathrm{~g} \mathrm{~L}^{-1}$ yeast extract, $5 \mathrm{~g} \mathrm{~L}^{-1}$ peptone, $10 \mathrm{~g} \mathrm{~L}^{-1}$ dextrose, $20 \mathrm{~g} \mathrm{~L}^{-1}$ agar) at $4{ }^{\circ} \mathrm{C}$. Cells were pre-adapted to the inhibitors by growing the inoculum in the hemicellulosic hydrolysate $\left(45.56 \mathrm{~g} \mathrm{~L}^{-1}\right.$ xylose) supplemented with $3 \mathrm{~g} \mathrm{~L}^{-1}$ malt extract, $3 \mathrm{~g} \mathrm{~L}^{-1}$ yeast extract and $5 \mathrm{~g} \mathrm{~L}^{-1}$ peptone, in Erlenmeyer flasks, at $30^{\circ} \mathrm{C}$, $200 \mathrm{rpm}$, for $16 \mathrm{~h}$. The initial cell concentration was $1 \mathrm{~g} \mathrm{~L}^{-1}$ estimated by a standard curve (dry cell mass vs. O.D. ${ }_{600 \mathrm{~nm}}$ ).

Fermentations were conducted in shaker in $125-\mathrm{mL}$ Erlenmeyer flasks with $50 \mathrm{~mL}$ of sunflower meal hemicellulosic hydrolysate (45.56 $\mathrm{g} \mathrm{L}^{-1}$ xylose), supplemented with the nutrients mentioned above, for $84 \mathrm{~h}$, according to a $2^{3}$ - CCRD (Central Composite Rotational Design) factorial scheme, with 8 major tests, 6 axial and 3 central, totalizing 17 tests in different conditions of $\mathrm{pH}$, temperature and agitation (Table 1). The software Statistica 8.0 was used for data analysis.

Glucose, xylose, arabinose, acetic acid and ethanol concentrations were determined in a liquid chromatograph with refractive index detector, using a Phenomenex Rezex ROA Organic Acid H+ (8\%) $150 \times 7.8 \mathrm{~mm}$ column, eluent $0.005 \mathrm{~mol}$ $\mathrm{L}^{-1} \mathrm{H}_{2} \mathrm{SO}_{4}$, flow rate of $0.6 \mathrm{~mL} \mathrm{~min}^{-1}$ and oven temperature of $65^{\circ} \mathrm{C}$. Furfural and HMF were analyzed using a Restek Allure $\mathrm{C} 185 \mu \mathrm{m} 4.6 \times 250 \mathrm{~mm}$ column, UV/VIS detector at $276 \mathrm{~nm}$, eluent acetonitrile: water (1:8) with $1 \%$ acetic acid, flow rate 0.6 $\mathrm{mL} \mathrm{min}^{-1}$ at room temperature. Standard curves were prepared with high purity compounds (98-99\%, Vetec and Sigma).

Total phenols were assayed according to the Folin Ciocalteu method (Singleton et al., 1999), using a standard curve of vanillin (purity 98\%, Synth).

Table 1. Encoded and real values of the independent variables $\mathrm{pH}$, temperature and agitation and the respective levels of variation for the $2^{3}$ CCRD (Central Composite Rotational Design)

\begin{tabular}{|c|c|c|c|c|c|c|}
\hline \multirow{3}{*}{$\begin{array}{c}\text { Experiment/ } \\
\text { test }\end{array}$} & \multicolumn{6}{|c|}{ Independent variables } \\
\hline & \multicolumn{2}{|c|}{ Agitation (rpm) } & \multicolumn{2}{|c|}{$\mathrm{pH}$} & \multicolumn{2}{|c|}{ Temperature $\left({ }^{\circ} \mathrm{C}\right)$} \\
\hline & Encoded & Real & Encoded & Real & Encoded & Real \\
\hline 1 & -1 & 100 & -1 & 4.5 & -1 & 25 \\
\hline 2 & -1 & 100 & 1 & 5.5 & -1 & 25 \\
\hline 3 & -1 & 100 & -1 & 4.5 & 1 & 35 \\
\hline 4 & -1 & 100 & 1 & 5.5 & 1 & 35 \\
\hline 5 & 1 & 200 & -1 & 4.5 & -1 & 25 \\
\hline 6 & 1 & 200 & 1 & 5.5 & -1 & 25 \\
\hline 7 & 1 & 200 & -1 & 4.5 & 1 & 35 \\
\hline 8 & 1 & 200 & 1 & 5.5 & 1 & 35 \\
\hline 9 & 0 & 150 & -1.68 & 4.2 & 0 & 30 \\
\hline 10 & 0 & 150 & 1.68 & 5.9 & 0 & 30 \\
\hline 11 & 0 & 150 & 0 & 5 & -1.68 & 22 \\
\hline 12 & 0 & 150 & 0 & 5 & 1.68 & 38 \\
\hline 13 & -1.68 & 66 & 0 & 5 & 0 & 30 \\
\hline 14 & 1.68 & 234 & 0 & 5 & 0 & 30 \\
\hline 15 & 0 & 150 & 0 & 5 & 0 & 30 \\
\hline 16 & 0 & 150 & 0 & 5 & 0 & 30 \\
\hline 17 & 0 & 150 & 0 & 5 & 0 & 30 \\
\hline
\end{tabular}

\section{Results AND Discussion}

Chemical characterization of sunflower meal resulted in the following composition: $32.93 \%$ cellulose, $30.90 \%$ hemicellulose, $26.62 \%$ lignin, $5.05 \%$ ash, $27.93 \%$ protein and $1.60 \%$ lipids.

The sunflower meal hemicellulosic hydrolysate presented the following sugar composition: glucose $8.06 \mathrm{~g} \mathrm{~L}^{-1}$, xylose $49.93 \mathrm{~g} \mathrm{~L}^{-1}$ and arabinose $8.67 \mathrm{~g} \mathrm{~L}^{-1}$. Xylose content in sunflower hydrolysate was high, compared to the hemicellulosic hydrolysates obtained from other materials such as sorghum straw, $17.69 \mathrm{~g} \mathrm{~L}^{-1}$ (Sene et al., 2011), sugar cane bagasse, 
$17.85 \mathrm{~g} \mathrm{~L}^{-1}$ (Marton et al., 2006), rice straw, $18.33 \mathrm{~g} \mathrm{~L}^{-1}$ (Mussatto \& Roberto, 2004) and wheat straw, $19.50 \mathrm{~g} \mathrm{~L}^{-1}$ (Canilha et al., 2005).

The inhibitors concentrations (acetic acid $3.56 \mathrm{~g} \mathrm{~L}^{-1}$, furfural $0.03 \mathrm{~g} \mathrm{~L}^{-1}$, HMF $0.03 \mathrm{~g} \mathrm{~L}^{-1}$ and total phenols $0.89 \mathrm{~g} \mathrm{~L}^{-1}$ ) are within or under the range of values usually found in other sources of hemicellulosic hydrolysates, in general, 1-3.41 $\mathrm{g} \mathrm{L}^{-1}$ of acetic acid, 0.04-0.26 $\mathrm{g} \mathrm{L}^{-1}$ of furfural, 0.008-1.56 $\mathrm{g} \mathrm{L}^{-1}$ of HMF and 2.12-2.23 $\mathrm{g} \mathrm{L}^{-1}$ of total phenols (Mussatto \& Roberto, 2004; Canilha et al., 2005; Marton et al., 2006; Villarreal et al., 2006; Sene et al., 2011).

After detoxification, the sugar composition in the hydrolysate was $45.56 \mathrm{~g} \mathrm{~L}^{-1}$ of xylose, $7.4 \mathrm{~g} \mathrm{~L}^{-1}$ of glucose, $7.82 \mathrm{~g} \mathrm{~L}^{-1}$ of arabinose, with a slight reduction of sugars (8$10 \%)$. Acetic acid concentration was reduced by $58 \%$ reaching the value of $1.5 \mathrm{~g} \mathrm{~L}^{-1}$. Total phenols, furfural and HMF were not detected in the detoxified hydrolysate. It has been reported that fermentations of steam exploded wheat straw by $S$. stipitis were completely inhibited by a synergistic effect due to the presence of $1.5 \mathrm{~g} \mathrm{~L}^{-1}$ of acetic acid, $0.15 \mathrm{~g} \mathrm{~L}^{-1}$ of furfural and $0.05 \mathrm{~g} \mathrm{~L}^{-1}$ of HMF (Bellido et al., 2011), the same acetic acid concentration found in this work after detoxification. However, the development of a $P$. stipitis more tolerant to acetic acid and other inhibitory components present in acid hydrolysates is possible through a simple adaptation of cells (Nigam, 2001).

Xylose consumption was strongly influenced by the different conditions employed. The highest xylose consumption was observed in the condition $14\left(\mathrm{pH} \mathrm{5,30}{ }^{\circ} \mathrm{C}\right.$ and $\left.234 \mathrm{rpm}\right)$, which was very similar to the xylose consumption at the central point triplicates - treatments 15,16 and $17(\mathrm{pH} \mathrm{5}$, $30{ }^{\circ} \mathrm{C}$ and $150 \mathrm{rpm}$ ). No xylose assimilation was observed in

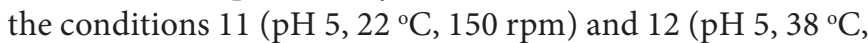
$150 \mathrm{rpm}$ ). Results suggest that the furthest temperature values employed $\left(22\right.$ and $38{ }^{\circ} \mathrm{C}$ ) reduced xylose assimilation, even at intermediate $\mathrm{pH}$ and agitation values ( $\mathrm{pH} 5$ and $150 \mathrm{rpm}$ ), which seemed to be favorable (data not shown).

Glucose uptake was faster in the conditions $6(\mathrm{pH} \mathrm{5.5}$, $\left.25^{\circ} \mathrm{C}, 200 \mathrm{rpm}\right)$ and $5\left(4.5,25^{\circ} \mathrm{C}, 200 \mathrm{rpm}\right)$. Similarly to that observed for xylose, the condition $12\left(\mathrm{pH} \mathrm{5}, 38^{\circ} \mathrm{C}, 150 \mathrm{rpm}\right)$ had strong negative influence on the consumption of glucose. Arabinose concentrations remained unaltered in most of the tests (data not shown), similar to an observation related in a previous work carried out with S. stipitis ATCC 58376 grown in sunflower meal hemicellulosic hydrolysate (Camargo \& Sene, 2014).

Growth profile seemed to be directly affected by $\mathrm{pH}$, temperature and agitation and their combinations. In general, high growth was related to high agitation ( $\geq 150 \mathrm{rpm}$ ) (data not shown). By comparing the growth profile in the conditions 6

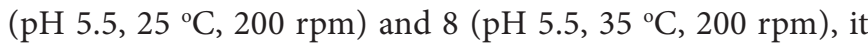
was observed that the higher temperature in the condition 8 probably affected growth negatively. High growth was also observed at intermediate levels of $\mathrm{pH}$ and temperature, i.e., $\mathrm{pH} 5.0$ and $30^{\circ} \mathrm{C}$, regardless of the agitation rate (treatments 13,14 and the central point repetitions), as well as in the treatment $10\left(\mathrm{pH} \mathrm{5.84,30}{ }^{\circ} \mathrm{C}, 150 \mathrm{rpm}\right)$.

The maximum ethanol concentration $\left(13.31 \mathrm{~g} \mathrm{~L}^{-1}\right)$ was obtained in the treatment $14\left(\mathrm{pH} 5.0,30{ }^{\circ} \mathrm{C}\right.$ and $\left.234 \mathrm{rpm}\right)$, which coincided with the highest consumption of xylose. Very similar values (average of $13.27 \mathrm{~g} \mathrm{~L}^{-1}$ ) were observed in the replicates of the central point - tests 15,16 and $17(\mathrm{pH}$ 5.0, $30^{\circ} \mathrm{C}$ and $150 \mathrm{rpm}$ ), which also presented high xylose assimilation. In the experiment $11\left(\mathrm{pH} 5.0,22^{\circ} \mathrm{C}, 150 \mathrm{rpm}\right)$ and $12\left(\mathrm{pH} 5.0,38^{\circ} \mathrm{C}, 150 \mathrm{rpm}\right)$, the lowest and highest temperatures strongly influenced the process, since ethanol was not produced. Low $\mathrm{pH}$ values ( $\mathrm{pH} 4.2$ and 4.5) and agitation $(66 \mathrm{rpm})$ may also be associated with a low ethanol production.

Similar ethanol yields $\left(0.46-0.50 \mathrm{~g} \mathrm{~g}^{-1}\right)$ were observed at $72 \mathrm{~h}$ in many of the tested conditions, except in the treatments 11 and 12, in which ethanol was not produced and assay 09 and 10 (0.41 and $0.40 \mathrm{~g} \mathrm{~g}^{-1}$, respectively). In most assays, the ethanol yield decreased slightly until $84 \mathrm{~h}$. In contrast, for treatment 14 ethanol yield was 0.40 and $0.45 \mathrm{~g} \mathrm{~g}^{-1}$ at 72 and 84 $\mathrm{h}$, respectively. In studies using the yeast $S$. stipitis NRRLY-7124 grown in semi-defined medium containing $90 \mathrm{~g} \mathrm{~L}^{-1}$ xylose, an yield of $0.32 \mathrm{~g} \mathrm{~g}^{-1}$ ethanol and productivity of $0.32 \mathrm{~g} \mathrm{~L}^{-1} \mathrm{~h}^{-1}$ was obtained (Silva et al., 2011). When this same strain was used for ethanol production from sugarcane hemicellulosic hydrolysate, ethanol yield was $0.39 \mathrm{~g} \mathrm{~g}^{-1}$ (Liu et al., 2011).

Thus, the results obtained in the present work were similar or even higher than those mentioned above, which shows that the sunflower hydrolysate may represent an alternative source of xylose to ethanol production. However, volumetric productivity of ethanol was only $0.158 \mathrm{~g} \mathrm{~L}^{-1} \mathrm{~h}^{-1}$, which may be increased by using a higher cell density. According to Ding et al. (2009), obtaining quantitative data concerning the impact of inoculation size on yeast growth and metabolism is of great importance for industrial ethanol fermentation process.

Pareto charts for ethanol production (Figure 1) show the standardized effects at a significance level of $0.05(p<0.05)$. The quadratic temperature factor produced the most significant effect on the response variable ethanol production during the fermentation process, exerting a negative influence. This effect was even greater (-2023.94) at $72 \mathrm{~h}$ and followed by a reduction at $84 \mathrm{~h}(-1131.66)$. Linear agitation was the second most significant effect at $24 \mathrm{~h}(149.7203)$ and $48 \mathrm{~h}$ (83.7899) and the third most significant effect at $72 \mathrm{~h}$ (484.07), followed by a reduction at $84 \mathrm{~h}(418.6215)$. The interactions among independent variables, agitation $\mathrm{x}$ temperature (1 and 3 ), agitation $\mathrm{x} \mathrm{pH}$ ( 1 and 2 ) and $\mathrm{pH} \times$ temperature (2 and 3 ) were significantly higher at $72 \mathrm{~h}$, subsequently decreasing at $84 \mathrm{~h}$. There was no interaction between the variables linear agitation $\mathrm{x}$ linear $\mathrm{pH}$ at $84 \mathrm{~h}$.

At the fermentation time of $48 \mathrm{~h}$, there was no interaction between variables, while at 24,72 and $84 \mathrm{~h}$ there was interaction between all variables with coefficient of determination of $0.82,0.82$ and 0.77 , respectively and p-value less than 0.05 . According to the analysis model for the fermentations at times of 24,72 and $84 \mathrm{~h}$, the F-value calculated was respectively 1.6, 1.47 and 1.27 times the F-tabulated value. In general, as there was a strong interaction between the linear and quadratic variables at 24 and $72 \mathrm{~h}$ and reduction of the interactions at $84 \mathrm{~h}$, data of 24 and $72 \mathrm{~h}$ were used to construct the response surface graphs (Figure 2). 

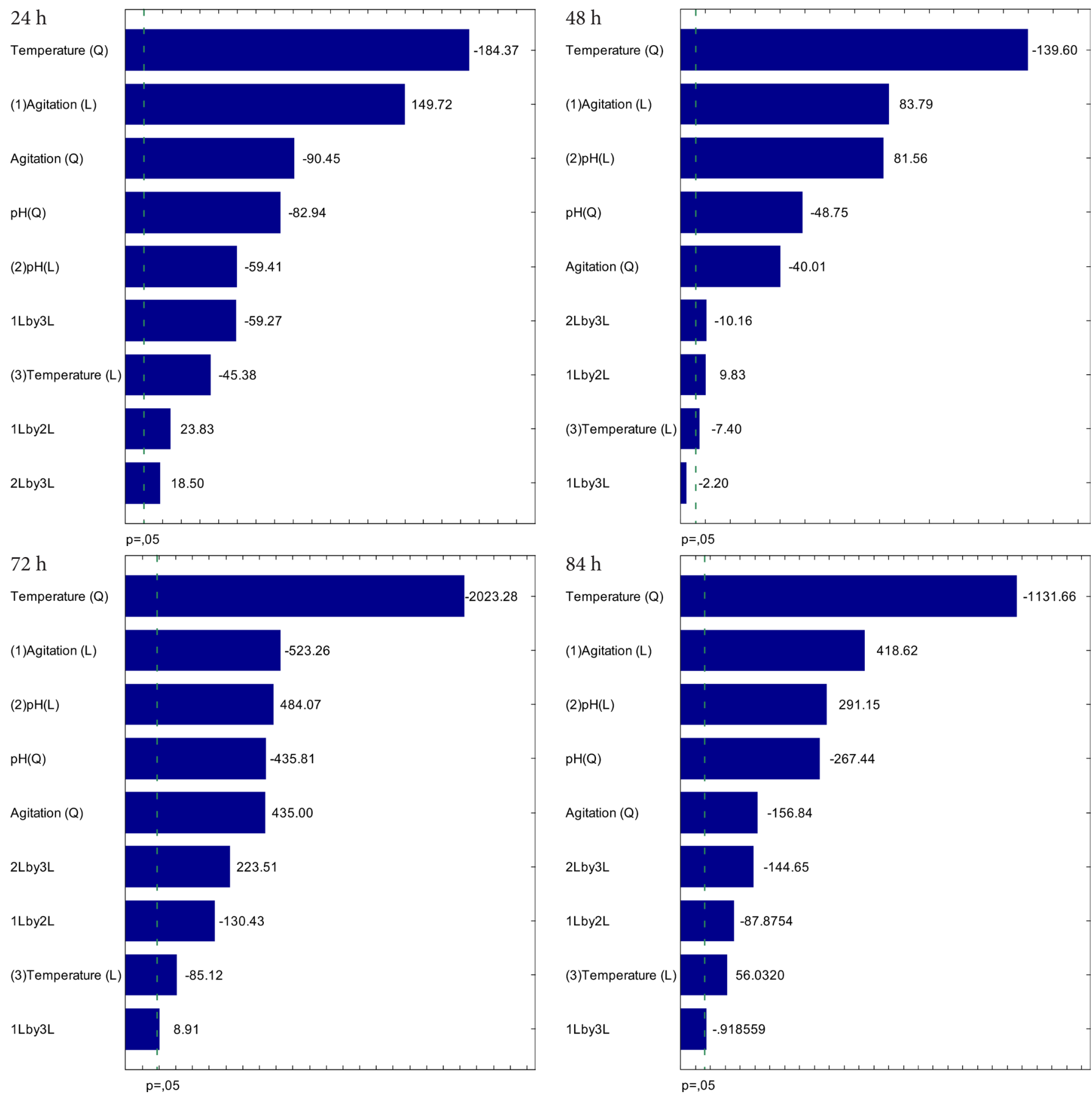

Figure 1. Pareto charts for estimation of the effects of $\mathrm{pH}$, temperature and agitation on the response ethanol production after $24,48,72$ and $84 \mathrm{~h}$

Figure $2 \mathrm{~A}$ and $2 \mathrm{D}$ show the quadratic effect of $\mathrm{pH}$ and agitation on the response ethanol production at 24 and $72 \mathrm{~h}$, respectively, in which it is evident that the greatest contribution to ethanol production occurred at the intermediate levels of $\mathrm{pH}$ and agitation. A higher ethanol production was also observed at the intermediate levels of temperature and agitation (Figure $2 \mathrm{~B}$ and $2 \mathrm{E}$ ) as well as at intermediate levels of temperature and $\mathrm{pH}$ (Figures $2 \mathrm{C}$ and $2 \mathrm{~F}$ ). Thus, by evaluating all the data together, it was possible to conclude that the production of ethanol was favored at $\mathrm{pH}$ values near 5 , agitation between 180-200 rpm and temperature near $30^{\circ} \mathrm{C}$.

A model is considered adequate and close to the optimization when it presents itself as quadratic model. Adequate models were obtained at $72 \mathrm{~h}$, when the variables showed the greatest influences on ethanol production.
Based on the results obtained after the completion of the design ( $2^{3}$ CCRD), all responses were optimized simultaneously, considering the desirable values for each one. By the interpolation of the results obtained at $72 \mathrm{~h}$, it was possible to verify that the optimal conditions corresponded to $\mathrm{pH}$ of 5.25 , temperature of $29.0^{\circ} \mathrm{C}$ and agitation of $198 \mathrm{rpm}$. The fermentations carried out in triplicate at the optimized conditions (Figure 3) led to a final ethanol concentration of $13.92 \mathrm{~g} \mathrm{~L}^{-1}$, which corresponded to an ethanol yield of $0.49 \mathrm{~g} \mathrm{~g}^{-1}$ and an efficiency of $96 \%$ compared to the theoretical yield. At this condition, ethanol production increased by $4.38 \%$ and volumetric ethanol productivity increased by $4.65 \%$ compared to the treatment 14 .

Although the favorable conditions for the ethanol production by $S$. stipitis ATCC 58376 in sunflower biomass 

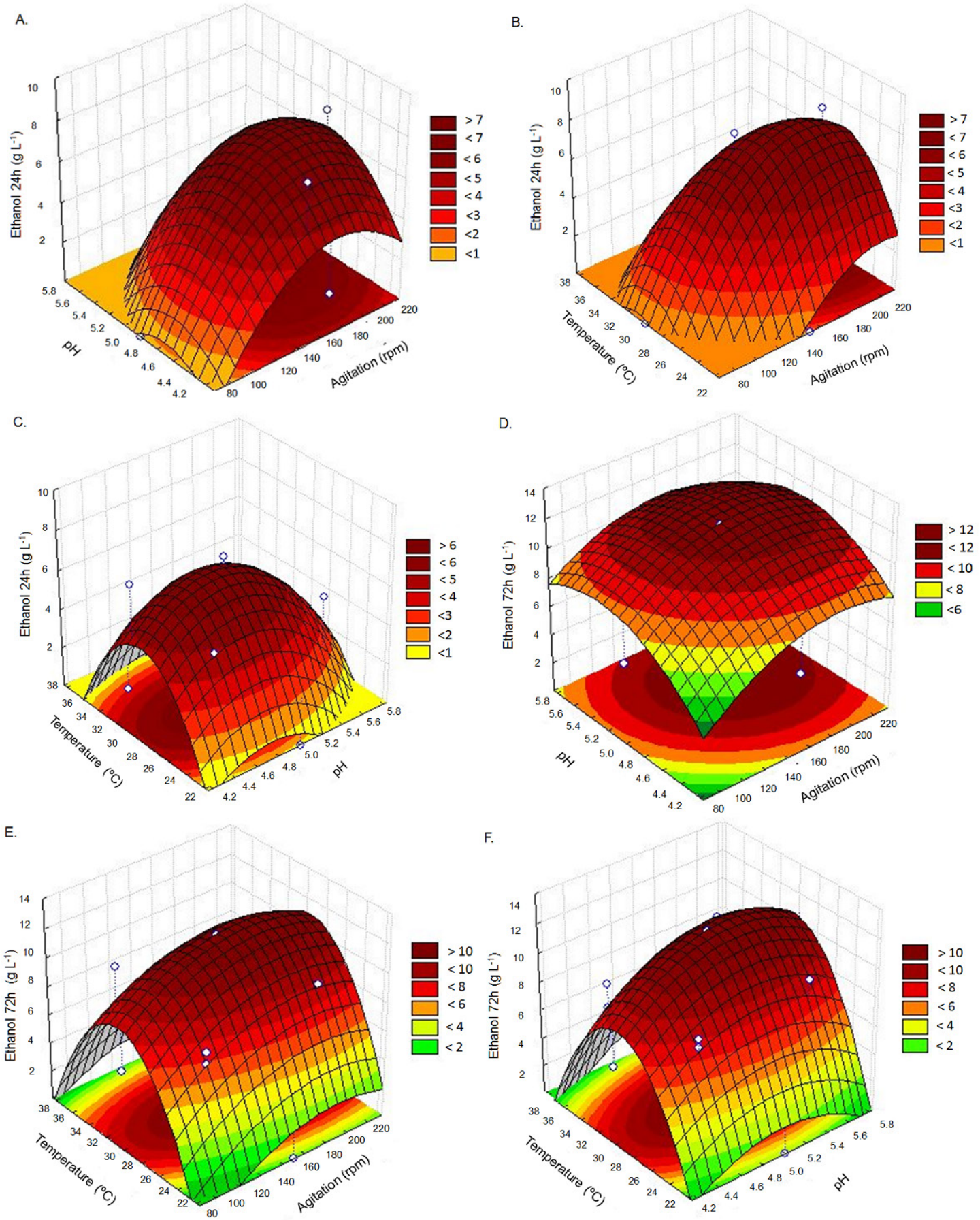

Figure 2. Surface response graphs ( $\mathrm{pH} x$ agitation, temperature $\mathrm{x}$ agitation and $\mathrm{pH} \times$ temperature) for ethanol production after 24 (ABC) and $72 \mathrm{~h}(\mathrm{DEF})$

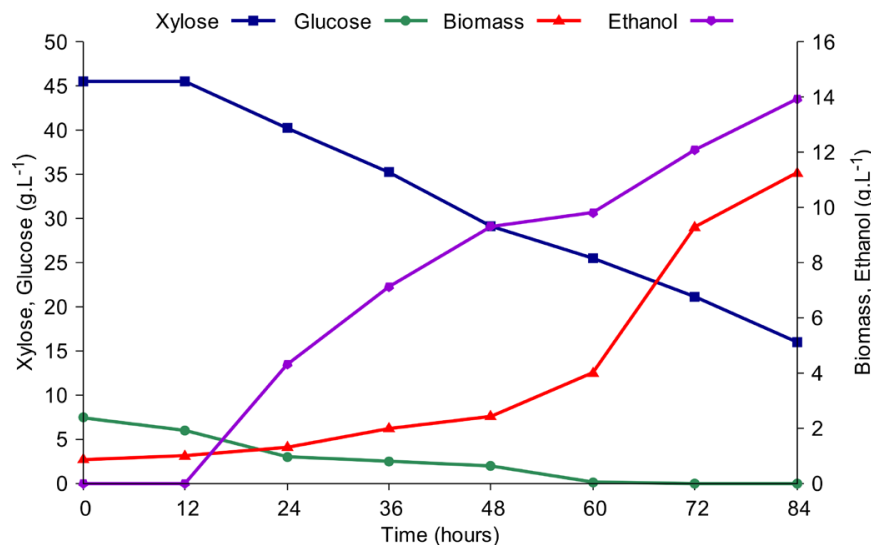

Figure 3. Kinetic profiles of fermentation performed at the optimized conditions hemicellulosic hydrolysate have been clearly evidenced, the low cell concentration $\left(1 \mathrm{~g} \mathrm{~L}^{-1}\right)$ initially used as inoculum may have been responsible for the low productivity. High cell-density fermentation can improve the productivity of final products and shorten fermentation time (Liu, 2012). High cell density of Saccharomyces cerevisiae strains was proven to provide effective fermentation at high sugar concentrations while mitigating some inhibitory effects of softwood hydrolysates (Kapu et al., 2013).

\section{Conclusions}

1. The use of pre-adapted cells to the hydrolysate as inoculum along with the optimization of conditions through experimental design, demonstrated that the sunflower meal 
hemicellulosic hydrolysate is feasible for ethanol production by $S$. stipitis ATCC.

2. The sunflower meal hemicellulose hydrolysate presented the advantage of having high sugar concentration, which eliminates the need for a concentration step, resulting in savings in the process of ethanol production, a fuel of great importance for the Brazilian economy.

\section{Acknowledgements}

The authors thank the Coordination for the Improvement of Higher Education Personnel - CAPES for the scholarship granted to Bruna Tavares.

\section{Literature Cited}

Bellido, C.; Bolado, S.; Coca, M.; Lucas, S.; Gonzalez-Benito, G.; Garcia-Cubero, M. T. Effect of inhibitors formed during wheat straw pretreatment on ethanol fermentation by Pichia stipitis. Bioresource Technology, v.102, p.10868-10874, 2011. http:// dx.doi.org/10.1016/j.biortech.2011.08.128

Camargo, D.; Gomes, S. D.; Felipe, M. G. A.; Sene, L. Response of byproducts of sunflower seed processing to dilute-acid hydrolysis aiming fermentable sugars production. International Journal of Food, Agriculture and Environment, v.12, p.239-246, 2014a.

Camargo, D.; Gomes, S. D.; Sene, L. Ethanol production from sunflower meal biomass by simultaneous saccharification and fermentation (SSF) with Kluyveromyces marxianus ATCC 36907. Bioprocess and Biosystems Engineering, v.37, p.2235-2242, 2014b. http://dx.doi.org/10.1007/s00449-014-1201-x

Camargo, D.; Sene, L. Production of ethanol from the hemicellulosic fraction of sunflower meal biomass. Biomass Conversion and Biorefinery, v.4, p.87-93, 2014.

Canilha, L.; Carvalho, W.; Silva, J. B. A. e. Influence of medium composition on xylitol bioproduction from wheat straw hemicellulosic hydrolysate. World Journal of Microbiology and Biotechnology, v.21, p.1087-1093, 2005. http://dx.doi.org/10.1007/ s11274-004-8342-z

Canilha, L.; Chandel, A. K.; Milessi, T. S. S.; Antunes, F. A. F.; Freitas, W. L. C.; Felipe, M. G. A.; Silva, S. S. Bioconversion of sugarcane biomass into ethanol: An overview about composition, pretreatment methods, detoxification of hydrolysates, enzymatic saccharification, and ethanol fermentation. Journal of Biomedicine and Biotechnology, v.2012, p.1-15, 2012. http:// dx.doi.org/10.1155/2012/989572

Díaz, M. J.; Ruiz, E.; Romero, I.; Cara, C.; Moya, M.; Castro, E. Inhibition of Pichia stipitis fermentation of hydrolysates from olive tree cuttings. World Journal Microbiology and Biotechnology, v.25, p.891-899, 2009. http://dx.doi.org/10.1007/s11274-0099966-9

Ding, M. Z.; Tian, H. C.; Cheng, J. S.; Yuan, Y. J. Inoculum sizedependent interactive regulation of metabolism and stress response of Saccharomyces cerevisiae revealed by comparative metabolomics. Journal of Biotechnology, v.144, p.279-286, 2009. http://dx.doi.org/10.1016/j.jbiotec.2009.09.020

Du Preez, J. C.; Bosh, M.; Prior, B. A. Xylose Fermentation by Candida shehatae and Pichia stipitis: Effects of $\mathrm{pH}$, temperature and substrate concentration. Enzyme and Microbial Technology, v.8, p.360-364, 1986. http://dx.doi.org/10.1016/0141-0229(86)90136-5
Hernández, F.; López, M. J.; García, V.; Martínez, S.; Megías, M. D.; Madri, J. Influence of cereal type and the inclusion of sunflower meal as a source of additional dietary fibre on nutrient retention, growth performance and digestive organ size in broilers from one to twenty-one days of age. Animal Feed Science and Technology, v.165, p.251-257, 2011. http://dx.doi.org/10.1016/j. anifeedsci.2011.03.006

Kapu, N. S.; Piddocke, M.; Saddler, J. N. High gravity and high cell density mitigate some of the fermentation inhibitory effects of softwood hydrolysates. AMB Express, v.3, p.1-9, 2013. http:// dx.doi.org/10.1186/2191-0855-3-15

Krahulec, S.; Kratzer, R.; Karin, L.; Nidetzky, B. Comparison of Scheffersomyces stipitis strains CBS 5773 and CBS 6054 with regard to their xylose metabolism: Implications for xylose fermentation. Microbiology Open, v.1, p.64-70, 2012. http://dx.doi.org/10.1002/ mbo3.5

Liu, S.; Zhijjie, S.; Shupe, A.; Liu, T.; Anidon, T. E. Particle properties of sugar maple hemicellulose hydrolysate and its influence on growth and metabolic behavior of Pichia stipitis. Bioresource Technology, v.102, p.2133-2136, 2011. http://dx.doi.org/10.1016/j. biortech.2010.08.097

Liu, Z. L. Microbial stress tolerance for biofuels: Systems biology, series microbiology monographs, n.22. Heidelberg: Springer, 2012.310p. http://dx.doi.org/10.1007/978-3-642-21467-7

Marton, J. M.; Felipe, M. G. A.; Silva, J. B. A.; Pessoa Júnior, A. Evaluation of the activated charcoals and adsorption conditions used in the treatment of sugarcane bagasse hydrolysate for xylitol production. Brazilian Journal Chemical Engineering, v.23, p.921, 2006. http://dx.doi.org/10.1590/S0104-66322006000100002

Mussatto, S. I.; Roberto, I. C. Optimal experimental conditions for hemicellulosic hydrolyzate treatment with activated charcoal for xylitol production. Biotechnology Progress, v.20, p.134-139, 2004. http://dx.doi.org/10.1021/bp034207i

Nigam, J. N. Development of xylose-fermenting yeast Pichia stipitis for ethanol production through adaptation on hardwood hemicellulose acid prehydrolysate. Journal of Applied Microbiology, v.90, p.208215, 2001. http://dx.doi.org/10.1046/j.1365-2672.2001.01234.x

Prior, B. A.; Killian, S. G.; Du Preez, J. C. Fermentation of D-xylose by the yeasts Candida shehatae and Pichia stipitis: Prospects and problems. Process Biochemistry, v.24, p.21-32, 1989.

Raclavska, H.; Juchelkova, D.; Roubicek, V.; Matysek, D. Energy utilization of biowaste - Sunflower-seed hulls for co-firing with coal. Fuel Processing Technology, v.99, p.13-20, 2011. http:// dx.doi.org/10.1016/j.fuproc.2010.03.006

Scordia, D.; Cosentino, C. L.; Lee, J. W.; Jeffries, T. W. Bioconversion of giant reed (Arundodonax L.) hemicellulose hydrolysate to ethanol by Scheffersomyces stipitis CBS6054. Biomass and Bioenergy, v.39, p.296-305, 2012. http://dx.doi.org/10.1016/j. biombioe.2012.01.023

Sene, L.; Arruda, P. V.; Oliveira, S. M. M.; Felipe, M. G. A. Evaluation of sorghum straw hemicellulosic hydrolysate for biotechnological production of xylitol by Candida guilliermondii. Brazilian Journal of Microbiology, v.42, p.1141-1146, 2011. http://dx.doi. org/10.1590/S1517-83822011000300036

Silva, J. P. A.; Mussatto, S. I.; Roberto, I. C.; Teixeira, J. A. Ethanol production from xylose by Pichia stipitis NRRL Y-7124 in a stirred tank bioreactor. Revista Brasileira de Engenharia, v.28, p.151-156, 2011. http://dx.doi.org/10.1590/s0104-66322011000100016 
Singleton, V.; Oorthofer, R.; Lamuela-Raventós, R. M. Analysis of total phenols and other oxidation substrates and antioxidants by means of Folin-Ciocateau reagent. Methods in Enzymology, v.299, p.152178, 1999. http://dx.doi.org/10.1016/S0076-6879(99)99017-1

Sluiter, J. B.; Ruiz, R. O.; Scarlata, C. J.; Sluiter, A. D.; Templeton, D. W. Compositional analysis of lignocellulosic feedstocks. 1. Review and description of methods. Journal of Agricultural and Food Chemistry, v.58, p.9043-9053, 2010. http://dx.doi.org/10.1021/jf1008023
USDA - United States Department of Agriculture. Oilseeds and products annual. http://www.fas.usda.gov/data/eu-28-oilseedsand-products-annual. 15 Apr. 2015.

Villarreal, M. L. M.; Prata, A. M. R.; Felipe, M. G. A.; Silva, J. B. A. e. Detoxification procedures of eucalyptus hemicellulose hydrolysate for xylitol production by Candida guilliermondii. Enzyme Microbial Technology, v.40, p.17-24, 2006. http://dx.doi. org/10.1016/j.enzmictec.2005.10.032 